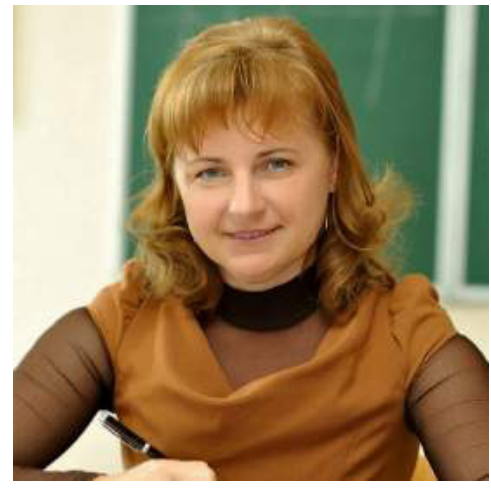

\section{Руслана Романишин,}

кандидат педагогічних наук, доцент кафедри фрахових методик і технологій початкової освіти, ДВНЗ «Прикарпатський національний університет імені Василя Стефраника» (м. Івано-Франківськ, Україна)

\author{
Ruslana Romanyshyn, \\ Candidate of Pedagogical Sciences, Associate Professor, \\ Department of Professional Methods and Technologies \\ of Primary Education, \\ Vasyl Stefanyk Precarpathian National University \\ (Ivano-Frankivsk, Ukraine) \\ ruslanaromanyshyn@ukr.net \\ ORCID ID 0000-0001-8480-2702
}

\title{
ОБЧИСЛЮВАЛЬНЕ ВМІННЯ ТА ОБЧИСЛЮВАЛЬНА НАВИЧКА: СУТНІСТЬ І СПІВВІДНОШЕННЯ ПОНЯТЬ
}

Анотація. У статті аналізується проблема формування обчислювальних умінь і навичок як важливих завдань початкової школи, що складають базис відповідної компетентності, необхідної молоді для життя в сучасному суспільстві. 3 метою визначення в майбутньому ефективних шляхів їх формування здійснюється аналіз європейських та вітчизняних документів, методичної літератури, що засвідчують використання авторами різних термінів «обчислювальне вміння» та «обчислювальна навичка» й актуалізують потребу в дослідженні цих понять. Для цього був застосований теоретичний метод дослідження - аналіз, систематизація та узагальнення науково-методичної літератури для порівняння й зіставлення різних підходів до представленої проблеми та розкриття вжитих у публікації дефініцій.

Було встановлено, що в психолого-методичній літературі поняття уміння та навичка різними групами вчених визначаються по-різному. Одна група вчених поняття вміння розуміє ширше за поняття навички, і відповідно до цього підходу знання і навички є основою вміння. Інші науковці вмінням називають проміжний етап оволодіння новим способом дії, заснованим на знанні, і відповідне правильне використання цього знання, яке ще не досягло рівня навички, у процесі вирішення певного класу задач.

3'ясовано, що обидві думки є правомірними, однак неоднозначність трактування поняття уміння пов'язана 3 тим, що вчені розглядають різні види вмінь. На основі методичної літератури та власних узагальнень пропонуємо в контексті обчислювальних умінь вживати терміни просте вміння та ускладнене вміння. Визначено ознаки кожного виду вмінь, подається загальне визначення обчислювального вміння як здатності успішно здійснювати обчислювальну діяльність, яка ґрунтується на засвоєному способі дії, базованому, в свою чергу, на знаннях його теоретичних основ та навичках виконання дій і операцій, що складають обчислювальний прийом.

Зокрема, під простим умінням здійснювати обчислення розуміємо вміння виконувати дії, що містять кілька послідовних операцій, вибір яких є однозначним. Ускладненим умінням називаємо вміння здійснювати дії за наявності розгалужень: в залежності від результату виконання попереднього кроку реалізація дії відбувається за одним з кількох варіантів. Таких розгалужень може бути одне і більше, що і визначає складність такого вміння.

Ключові слова: обчислювальне вміння, просте вміння, ускладнене вміння, обчислювальна навичка, операція, дія, обчислювальна діяльність, обчислювальний прийом.

\section{NUMERACY HABIT AND NUMERACY SKILLS: ESSENCE AND CORELATION BETWEEN THE NOTIONS}

Abstract. The article analyses the problem of the formation of numeracy abilities and skills, as important tasks of primary school, which forms the basis of the appropriate competence necessary for a young person to live in a modern society.

In order to determine effective ways of their formation in the future, an analysis of European and national documents and methodological literature has been carried out. The latter testified that the authors use different terms: «numeracy skill» and «numeracy habit»; hence, the need for the study of these concepts is necessitated.

For this purpose the theoretical method of research was used - the analysis, systematization and generalization of scientific and methodological literature for comparing and contrasting different approaches to the presented problem and disclosing the definitions used in the article.

It was found that in psychological and methodological literature, the concepts of skill and habit are determined in different ways by different groups of scientists. One group of scientists understands the notion of skill broader than the notion of habit and, according to this approach, knowledge and habit are the basis of skill. Other scholars call a skill an intermediate stage 
of mastering a new way of action based on knowledge and the proper use of this knowledge in the process of solving a certain class of tasks that has not yet reached the level of habit.

It is found that both thoughts are legitimate, but the ambiguity of the interpretation of the notion of skill is due to the fact that scientists are considering different types of skills. On the basis of methodological literature and own generalizations, we offer simple skills and complicated skills in the context of numeracy skills. The features of each type of skill are determined and the general definition of numeracy skill as an ability to carry out numeracy activity, which is based on the learned way of action based in its turn on knowledge of its theoretical foundations and habits of performing actions and operations that make up the numeracy technique, successfully.

In particular, under the simple numeracy skill we understand the ability to perform actions that contain several consecutive operations, the choice of which is unambiguous. We call the complicated numeracy skills the ability to perform actions in the presence of their options, i.e. depending on the outcome of the previous step, implementation of the action takes place in one of several variants. There can be one or more options; and based on this the complexity of such skill is determined.

Keywords: numeracy skill, simple skill, complicated skill, numeracy habit, operation, action, numeracy activity, numeracy technique.

\section{ВСТУП}

Постановка проблеми. На початку 2000-х років європейська освітянська спільнота актуалізувала роботу 3 визначення переліку базових умінь і навичок, необхідних молоді для життя в сучасному суспільстві. Саме про це йшлося у 2001 році на засіданні Європейської Ради у Стокгольмі в доповіді «Про конкретні майбутні завдання освіти та професійної підготовки» (On the Concrete Future Objectives of Education and Training Systems, 2001 p.). Подальшого обговорення проблема базових умінь і навичок, необхідних молоді для життя в сучасному суспільстві, набула на засіданні Європейської Ради у Барселоні 2002 року. Треба відзначити, що до переліку базових умінь і навичок, поряд з грамотністю читання та письма, також віднесено лічбу, тобто обчислювальну навичку, про що зазначено в повідомленні Європейської комісії Європейській Раді і Європейському Парламенту «Ефективність та справедливість в європейських системах освіти і профресійної підготовки» (Efficiency and Equity in European Education and Training Systems, 8.09.2006 р.) [11, с. 51].

Водночас у країнах Європейського Союзу активно долучилися до дослідження природи ключових компетентностей з метою їх ефективного використання в системах освіти держав - членів проекту DeSeCo. Важливим напрацюванням у цій царині стало дослідження «Ключові компетентності. Концепт, що розвивається у загальній середній освіті» (Кеу Competencies. A Developing Concept in General Compulsory Education), проведене у 2002 р. Європейською комісією. У звіті до цього дослідження ключові компетентності, які має формувати середня школа, об'єднано у сім груп, причому до першої групи ключових компетентностей віднесено і вміння лічити [11, с. 138].

Як бачимо, у європейських документах лічба розглядається або як базова навичка, або як уміння, або як компетентність, що спричиняє деяку невизначеність у термінології. Порівняння понять «уміння» і «навичка» 3 поняттям «компетентність» здійснено в документі «Освіта та підготовка в Європі: різні системи - спільні цілі до 2010 р.» (Education and Training in Europe: Diverse Systems, Shared Goals for 2010), у якому наголошено на тому, що компетентність включає такі характеристики, як знання, ставлення, вміння та цінності. 3 огляду на це Спільнота запропонувала перелік базових компетентностей, який у Барселонській редакції включав навички лічби (обчислювальні навички) [10, с. 16].

В оновленій редакції ключових компетентностей для навчання впродовж життя Європейського Парламенту та Ради (ЄC) від 17 січня 2018 року була виокремлена математична компетентність, до складу якої входить обчислювальна навичка [19]. Така позиція європейської спільноти щодо визначення ключових компетентностей була результатом попередньо проведених досліджень. Так, у країнах, що є членами Організації європейського економічного співробітництва (Organisation for Economic Cooperation and Development, OECD), опитування дорослих у 2012 виявило, що до 31,7\% володіють лише найнижчим рівнем обчислень [31, с. 3], а за результатами дослідження Міжнародної програми з оцінювання освітніх досягнень учнів (Programme for International Student Assessment, PISA), яке проводиться за координації цієї організації, у 2015 було встановлено, що кожен п'ятий учень європейських країн мав труднощі з обчисленнями [31, с. 14].

МЕТА I ЗАВДАННЯ ДОСЛІДЖЕННЯ - аналіз європейських та вітчизняних документів, які відносять вміння здійснювати обчислення до ключових компетентностей, та аналіз науково-методичної літератури 3 метою визначення понять «обчислювальне вміння» та «обчислювальна навичка».

МЕТОДИ ДОслІДЖЕНня: теоретичні - аналіз, систематизація, узагальнення науково-методичної літератури для порівняння і зіставлення різних підходів до представленої проблеми та розкриття змісту вжитих у публікації дефініцій.

\section{РЕЗУЛЬТАТИ ДОСЛІДЖЕННЯ}

Обчислювальна навичка віднесена європейською освітянською спільнотою до переліку ключових компетентностей, які є необхідними для ефективної життєдіяльності людини в оточуючому середовищі. Загальноєвропейські тенденції знайшли відображення й у вітчизняних нормативних документах, зокрема в проекті Національної стандартної класифікації освіти (НСКО), де зазначається, що програма початкової освіти спрямована на фрормування елементарних умінь, у тому числі й математичних (уміння кількісного мислення, тобто обчислювальне вміння) [17, с. 16].

Аналіз європейських та вітчизняних документів і методичної літератури свідчить про використання авторами різних термінів: «обчислювальне вміння» та «обчислювальна навичка», що актуалізує потребу в дослідженні цих понять.

3 огляду на психологічні дослідження такі поняття, як «дія», «вміння» і «навичка», $€$ характеристикою операційних складників учіння [23], а тому існує взаємозв'язок понять «уміння» та «навичка». Однак цей зв'язок розуміється вченими неоднозначно. 
Одна група вчених розуміє поняття вміння ширшим за поняття навички, і відповідно до цього підходу знання та навички є основою вміння (В. Бродовська, С. Гончаренко, В. Грушевський, І. Патрик, А. Петровський, Ю. Приходько, В. Юрченко, М. Гамезо, О. Петрова, Л. Орлова, Г. Костюк та ін.). Автори Є. Бойко Б. Ломов, В. Чебишева під умінням розуміють можливість здійснювати будь-яку діяльність, що формується на основі кількох навичок.

Відповідно до першого підходу, поняття «уміння» визначається як:

- $\quad$ поєднання знань і навичок, яке забезпечує успішне виконання діяльності [4, с. 93];

- $\quad$ сукупність знань і навичок, що забезпечують можливість виконання певної діяльності в певних умовах і, проходячи через ряд етапів фрормування, в кінцевому підсумку переростає в майстерність ітворчість [26, с. 379];

- $\quad$ готовність людини успішно виконувати діяльність, що ґрунтується на знаннях і навичках [18, с. 434] і є основою майстерності особистості [16];

- $\quad$ здатність належно виконувати певні дії, засновані на доцільному використанні людиною набутих знань і навичок, раніше набутого досвіду [6, с. 338] для виконання складних дій у різноманітних умовах [28, c. 143];

- $\quad$ володіння складною системою психічних і практичних дій, необхідних для регуляції діяльності наявними у суб'єкта знаннями і навичками [15].

Таким чином, за визначенням цих учених уміння $€$ основою успішного виконання діяльності і результатом одержаних знань та навичок. Водночас уміння є характеристикою і діяльності (сукупність знань про спосіб діяльності), і самої особистості (його застосування) [24, с. 2] та фрормується як синтез знань і навичок та як оволодіння людиною сукупністю операцій, що призводять до успішного виконання тієї чи іншої діяльності [5, с. 309]. Уміння - це готовність людини ефективно виконувати дії (або діяльність) відповідно до мети й умов, у яких необхідно діяти, а навичкою О. Савченко називає усталений спосіб виконання дій, сформований у результаті багаторазових повторень [22, с. 404]. На відміну від першої групи вчених, які розглядають уміння, що базується на навичках, інша група науковців (А. Данилов, В. Зінчеко, А. Смирнов, Б. Мещеряков та ін.) вважає умінням проміжний етап оволодіння новим способом дії, заснованим на якому-небудь правилі (знанні) і відповідним правильному використанню цього знання в процесі вирішення певного класу задач, а рівень навички досягається тоді, коли вміння у цьому способі автоматизується. Ці психологи умінням називають проміжний етап оволодіння новим способом дії, заснованим на знанні і відповідним правильним використанням цього знання в процесі вирішення певного класу задач, який ще не досяг рівня навички [2]. Автори Б. Ашмарін Є, А. Пуні, П. Рудик у дослідженнях з психології спорту під умінням розуміють можливість здійснювати будь-яку дію / операцію, а навичка розглядається як більш досконала стадія оволодіння діями.

Однак спільним в обох підходах до визначення вміння $€$ те, що знання становить основу вміння, його базис. Утворення вмінь $є$ складним процесом аналітико-синтетичної діяльності кори великих півкуль головного мозку, в ході якого створюються й закріплюються асоціації між завданнями застосувати знання на практиці [6, с. 338]. Загалом умінням $€$ свідомо контрольовані частини діяльності в головних проміжних пунктах і кінцевій меті [13]. Неоднозначність трактування поняття вміння, на нашу думку, пов'язана з тим, що вчені розглядають різні види вмінь. У психології розрізняють елементарні вміння, які йдуть відразу за знаннями та першим досвідом дій, і вміння, які проявляються як уміння-майстерність у виконанні діяльності, що виникає вже після вироблення навички. Так, Р. Павелків елементарними вміннями називає дії, які виникають на основі знань в результаті наслідування, а вміння-майстерність виникають вже на основі сформованих навичок і широкого кола знань. Оскільки діяльність складається з різноманітних дій, то і вміння їх виконувати також складається з низки умінь у виконанні окремих дій та операцій, і чим складнішою $є$ діяльність (до ії складу входить значна кількість дій / операцій), тим більшою майстерністю повинні характеризуватися вміння людини [13, с. 109]. Схожі міркування знаходимо і у визначенні педагогів. Зокрема, О. Вишневський також розрізняє два види вмінь: елементарне вміння, яке передує навичці і яке він ще називає первинним, та вміння-майстерність, яке спирається на знання і раніше набуті навички [3, с. 41]. В. Цетлін також виокремлює первинні вміння і другорядні та розглядає їх як компонент навчальної діяльності. За її визначенням, первинні вміння близькі до навичок, тобто до дій, що підлягають автоматизації і підкоряються правилу, а другорядні відмінні від навичок і не можуть бути автоматизовані, оскільки у власній основі не мають однозначного правила і передбачають застосування евристики [29].

Як бачимо, вчені лише частково пов'язують елементарні (первинні) вміння та вміння-майстерність (другорядні) з кількістю дій / операцій, що входять до їх складу; інший бік їх співвіднесення стосується можливості алгоритмізації дій чи застосування евристики. Отже, елементарні вміння містять одну чи кілька нескладних дій / операцій і підлягають автоматизації, а вміння-майстерність, у структурі яких велика кількість дій / операцій, ще й із можливим розгалуженням, тобто врахуванням конкретних умов, не є елементарними. Вони базуються на вже сорормованих навичках у виконанні дій / операцій, що їх складають, і не підлягають автоматизації.

Таким чином, обидва підходи до визначення вмінь є правомірними. Зокрема, вчені, які розглядають вміння як основу - базу навички, мають на увазі елементарні (нескладні) вміння, а дослідники, які, навпаки, вважають вміння заснованою на знаннях і навичках готовністю / здатністю до виконання діяльності, досліджують складні вміння, тобто вміння-майстерність. 
Більшість математичних дій, у тому числі й дій з виконання обчислень, є складними за своєю структурою, тому в нашому дослідженні дотримуємось першого підходу і вслід за Л. Фрідманом під умінням розуміємо свідоме застосування наявних в учня знань і навичок для виконання складних дій в різних умовах, тобто для розв'язування відповідних задач [28, с. 143].

Вихідними положеннями для нашого дослідження $є$ те, що знання та вміння взаємопов'язані як абстрактне (ідеальне) і конкретне (дія) [12]. Знання завжди існують в нерозривному зв'язку з тими чи іншими діями (вміннями), відтак їх взаємозумовленість слід розглядати завжди у зв'язку з конкретною метою навчання. Їх якість залежить від особливостей пізнавальної діяльності, в яку вони включені, і від широти включення цих знань в різні види діяльності [25, с. 16].

Майже всі вміння у виконанні обчислень охоплюють кілька дій / операцій, їх не можна засвоїти після першого досвіду, тому в контексті нашого дослідження не можна говорити про елементарне вміння, яке йде відразу за знаннями і першим досвідом дій. Але водночас серед обчислювальних умінь $€$ вміння, які підлягають автоматизації, оскільки містять невелику кількість послідовних дій / операцій, кожна з яких засвоюється на рівні навички; для таких умінь будемо використовувати термін просте уміння.

Також при вивченні математики в початковій школі говорити про вміння-майстерність не видається коректним. Але існують уміння у виконанні обчислень, складніші за своєю структурою, ніж розглянуті вище, що виявляється і в більшій кількості кроків, з можливими варіаціями умов - розгалуженнями; такі вміння назвемо ускладненими. Базис ускладнених умінь становлять прості вміння. Показником сформованості такого вміння $€$ свідоме його перенесення в нову ситуацію, на розв'язування нових завдань. Чим ширше перенесення, тим вищий рівень умінь виявляє учень [4, с. 93].

Ймовірно, що саме таке ускладнене вміння Н. Істоміна називає обчислювальним умінням, оскільки застосовує це означення як до усних, так і до письмових обчислень і визначає його як розгорнуте здійснення операцій (одна за одною), що супроводжується усвідомленням мети, способу дій і умов їх виконання. При цьому кожна операція повинна усвідомлюватися і контролюватися [7, с. 156-157]. Отже, під простим умінням здійснювати обчислення розуміємо вміння виконувати дії, що містять кілька операцій, і їх вибір є однозначним. Наприклад, при порозрядному додаванні учень має виконати наступні кроки: 1) подати перший доданок у вигляді суми розрядних доданків; 2) подати другий доданок у вигляді суми розрядних доданків; 3) додати десятки; 4) додати одиниці; 5) додати одержані результати. Як бачимо, всі кроки тлумачаться однозначно й відсутні розгалуження. У цьому випадку говоримо про уміння виконувати порозрядне додавання як просте вміння.

В основі простого вміння лежать навички виконання окремих дій та операцій, що його складають. 3 іншого боку, система цих дії та операцій у процесі багаторазового вправляння підлягає автоматизації, тобто може бути засвоєною на рівні навички. Таким чином, істотними ознаками простих умінь є невелика кількість кроків, які можуть бути однозначно потрактовані, оскільки не передбачають розгалужень.

Ці кроки складають основу обчислювального прийому, який у методичній концепції М. Бантової складається з ряду послідовних операцій (системи операцій), виконання яких призводить до знаходження результату необхідної арифметичної дії над цими числами. Вибір операцій у кожному прийомі визначається тими теоретичними положеннями, які використовуються в якості його теоретичної основи [1]. За визначенням Н. Істоміної, обчислювальний прийом можна представити у вигляді послідовності операцій, виконання кожної з яких пов'язана з певним математичним поняттям або властивістю [7, с. 156-157]. С. Скворцова прийомом обчислення називає орієнтувальну основу дії (ООД) [8, с. 19; 21, с. 24].

Водночас треба розуміти, що по мірі узагальнення прийому обчислення, його застосування для широкого кола випадків система дій та операцій може передбачати певні варіації умов, тобто розгалуження. Таким чином, просте вміння в результаті узагальнення й перенесення на інші випадки обчислення може перерости в ускладнене обчислювальне вміння.

Наприклад, при порозрядному відніманні двоцифрових чисел без переходу через розряд дії, що складають цей прийом, тлумачаться однозначно: 1) подати зменшуване у вигляді суми розрядних доданків; 2) подати від'ємник у вигляді суми розрядних доданків; 3) відняти десятки від десятків; 4) відняти одиниці від одиниць; 5) додати одержані результати. При порозрядному відніманні двоцифрових чисел з переходом через розряд дії, що складають цей прийом, також тлумачаться однозначно: 1) подати зменшуване у вигляді суми зручних доданків, де переший доданок десятки, але на 1 десяток менше; 2) подати від'ємник у вигляді суми розрядних доданків; 3) відняти десятки; 4) відняти одиниці; 5) додати одержані результати. При узагальненні прийому порозрядного віднімання двоцифрових чисел як для випадків віднімання без переходу через розряд, так і для випадків віднімання з переходом через розряд система операцій передбачає різні напрями міркування в залежності від відповіді на певне запитання: «Чи можна від одиниць зменшуваного відняти одиниці від'ємника?»; якщо можна, то зменшуване подаємо у вигляді суми розрядних доданків, якщо ні, то зменшуване подаємо у вигляді суми зручних доданків; далі міркування розгортається за однозначно визначеною схемою: відняти десятки; відняти одиниці; додати одержані результати.

Ознаками ускладнених умінь є наявність розгалужень: у залежності від результату виконання попереднього кроку реалізація дії відбувається за одним із кількох варіантів. Таких розгалужень може бути одне і більше, і, виходячи з цього, визначається складність такого уміння. 
Так, на відміну від уміння у виконанні порозрядного віднімання для будь-яких випадків обчислення, яке $є$ ускладненим, оскільки передбачає варіації на етапі оцінки можливостей віднімання одиниць певного розряду, дія письмового ділення передбачає низку кроків, більшість із яких є складними й передбачають розгалуження. Наприклад, при письмовому діленні першим кроком маємо визначати перше неповне ділене, причому ця дія містить кілька операцій: 1) визначити кількість цифр у дільнику; 2) відділити в діленому ліворуч стільки ж цифр; 3) прочитати одержане число з назвою розряду; 4) перевірити, чи можна це число розділити на дільник, щоб одержати хоч би одну одиницю цього розряду: якщо так, то знайдене число розрядних одиниць є першим неповним діленим; якщо ні, то відділяємо в діленому ліворуч ще одну цифру - одержане число розрядних одиниць і буде першим неповним діленим. Погоджуємося $з$ думкою С. Скворцової, яка зазначила, що дія письмового ділення складна за своєю структурою і передбачає поступове виконання ряду елементарних дій, які в свою чергу, утримують декілька операцій. У випадку, коли учень здобув навичку або вміння у виконанні складної дії, він виконує всі елементарні дії спільно одну за іншою. Але при засвоєнні складної дії кожна з елементарних дій, що складають ії̈, повинна бути засвоєною як самостійна дія [20].

У даному випадку вміння у виконанні письмового ділення є ускладненим, оскільки містить велику кількість кроків і передбачає розгалуження. Таких умінь у виконанні обчислень у початковому курсі математики не так багато, і вони всі стосуються або узагальнених прийомів усних обчислень, або письмових прийомів: додавання, віднімання; множення і ділення на одно- та двоцифрове число або ділення з остачею.

Оскільки і просте вміння у виконанні обчислень, й ускладнене вміння виникають уже після вироблення навички у виконанні дій / операцій, що його складають, то в нашому дослідженні дотримуємось визначення вміння в широкому сенсі як заснованої на знаннях і навичках готовності індивіда успішно виконувати певну діяльність. Тому під обчислювальним умінням розуміємо здатність успішно здійснювати обчислювальну діяльність, яка ґрунтується на засвоєному способі дії, базованому на знаннях його теоретичних основ і навичках виконання дій та операцій, що складають прийом обчислення.

Обчислювальні вміння класифікуємо на прості вміння у виконанні діяльності з обчислення, яка складається $з$ невеликої кількості дій / операцій і не передбачає розгалуження, та на ускладнені вміння, які характеризуються більшою кількістю дій / операцій і містять розгалуження.

Виходячи із класифікації вмінь Т. Шамової, обчислювальне вміння в контексті розгляду способів учіння віднесемо до спеціальних умінь, які визначаються спрямованістю діяльності на зміст навчального предмета [30]. За характером діяльності, відповідно до класифікації умінь О. Боброва та А. Усової, обчислювальні вміння відносяться до практичних, тобто до таких, які учні можуть використати при вирішенні низки задач не тільки в рамках того предмета, при вивченні якого здійснюється формування даного вміння, але й на уроках з інших предметів, а також у різноманітній практичній діяльності [27, с. 5].

Педагогічні дослідження дають підстави стверджувати, що в ході вправ елементарні вміння трансформуються в елементарні навички, на основі яких формуються складніші вміння, які внаслідок вправ стають навичками більш складної будови. Як результат - одну і ту саму дію можна назвати і вмінням, і навичкою [14, с. 9]. Стосовно нашого дослідження можна стверджувати, що просте вміння у виконанні обчислень, хоча й базується на наявних в учня навичках, у результаті вправ може бути автоматизоване і засвоєне ним на рівні навички більш складноїбудови. Таким чином, дію у виконанні окремих обчислень (зокрема з реалізації усних прийомів) можна називати і вмінням, і навичкою. За визначенням М. Бантової, обчислювальна навичка - це високий ступінь оволодіння обчислювальними прийомами, а сформувати в учнів обчислювальні навички - означає, що для знаходження числового значення будь-якого виразу потрібно знати, які операції і в якій послідовності потрібно швидко виконати [1, с. 39]. У сучасних дослідженнях такого ж визначення дотримується С. Скворцова [21, с. 24].

На відміну від уміння, навичка на думку Н. Істоміної, характеризуються згорнутим, значною мірою автоматизованим виконанням дії з пропуском проміжних операцій, коли контроль переноситься на кінцевий результат. У випадку усних обчислень, коли результат тієї чи іншої арифметичної дії учень запам'ятовує і відтворює механічно, не виконуючи при цьому проміжних операцій, учена називає автоматизованою навичкою [7, с. 156-157].

\section{ВИСНОВКИ ТА ПЕРСПЕКТИВИ ПОДАЛЬШИХ ДОСЛІДЖЕНЬ}

Якість обчислювальних умінь - простих і ускладнених - визначається теоретичними положеннями, на підставі яких засновано прийом обчислення: знанням правил, законів, властивостей, на основі яких виконується обчислювальна діяльність, а також знаннями змісту обчислювальних прийомів / алгоритмів, наявністю в учнів навичок у виконанні окремих дій / операцій, що є складниками прийому обчислення. Отже, з одного боку, обидва види обчислювальних умінь ґрунтуються на навичках у виконанні операцій усіх дій, що складають обчислювальну діяльність, а з іншого, - лише прості вміння підлягають автоматизації й переходять у навичку.

\section{СПИСОК ВИКОРИСТАНИХ ДЖЕРЕЛ}

[1] Бантова М. А. Система формирования вычислительных навыков. Начальная школа. 1993. № 11. С. 38-43.

[2] Большой психологический словарь. 4-е узд., расширенное. Сост. Б. Г. Мещеряков, В. П. Зинченко. М.: АСТ Москва; СПб.: Прайм. ЕВРОЗНАК, 2009. 811 с.

[3] Вишневський О. Теоретичні основи сучасної української педагогіки. Посібник для студентів вищих навчальних закладів. Дрогобич, 2006. 326 с.

[4] Возрастная и педагогическая психология. Учеб. Пособие для студентов пед. институтов по спец. 2121 «Педагогика и методика нач. обучения» / М. В. Матюхина, Т. С. Михальчик, Н. Д. Прокина и др. Под ред. М. В. Гамезо и др. М., 1984.256 с. 
[5] Гамезо М. В., Петрова Е. А., Орлова Л. М. Возрастная и педагогическая психология: Учеб. пособие для студентов всех специальностей педагогических вузов. М., 2003. 512 с.

[6] Гончаренко С. У. Український педагогічний словник. К., 1997. 375 с.

[7] Истомина Н. Б. Методика обучения математике в начальной школе: Развивающее обучение. Смоленск, 2005.272 с.

[8] Коваль Л. В., Скворцова С. О. Методика навчання математики: теорія і практика: Підручник для студентів за спеціальністю 6.010100 «Початкове навчання», освітньо- кваліфікаційного рівня «бакалавр» [2-ге вид., допов. і переробл.]. Х., 2011. 414 с.

[9] Костюк Г. С. Навчально-виховний процес і психічний розвиток особистості. Київ, 1989.608 с.

[10] Лодатко Є. Математична культура вчителя початкових класів. Рівне-Слов'янськ, 2011.324 с.

[11] Локшина О. І. Зміст шкільної освіти в країнах Європейського Союзу: теорія і практика (друга половина XX - початок XXI ст.). К., 2009. 404 с.

[12] Орлов В. И. Знания, умения, навыки и обучение. М., 1995. 212с.

[13] Павелків Р. В. Вікова психологія. К., 2015. 469 с.

[14] Педагогіка. За ред. А. М. Алексюка. К, 1985. 296 с.

[15] Петровский А. В. Общая психология. М., 1976. 479 с.

[16] Приходько Ю. О., Юрченко В. І. Психологічний словник-довідник: Навч.посіб. 2-ге вид. К., 2014. 314 с.

[17] Проект Національної стандартної класифікації освіти. URL: http://naps.gov.ua/uploads/files/sod/NSKO.

[18] Психологічний тлумачний словник сучасних термінів вікової та педагогічної психології. URL: http://psichology.com.ua/slovnik-n/;

[19] Рекомендація 2018/0008 (NLE) Європейського Парламенту та Ради (ЄC). URL: https://ec.europa. eu/education/sites / education/files/ recommendation-key-competences- lifelong-learning.pdf.

[20] Скворцова С. Вивчення письмового ділення в курсі початкової математики. «Початкова освіта». 2002. № 7 (151). С. 4-5.

[21] Скворцова С. Прийоми обчислення в курсі математики початкової школи. Матеріали міжнародної науково-методичної конференції «Проблеми математичної освіти» (ПМО - 2017), м. Черкаси, 26-28 жовтня 2017 р. Черкаси, 2017.248 с.

[22] Савченко О.Я. Дидактика початкової освіти: підручник для студентів пед. фракультетів. К., 2012.504 с.

[23] Скрипченко О. В., Долинська Л. В., Огороднійчук 3. В., Булах І. С., Зелінська Т. М. Вікова та педагогічна психологія: Навч. посібник для студ. вищих навч. закл. Вид. 2- ге, доп. К., 2007. 400с.

[24] Степашкина Л. Ю. Развитие общих учебных умений и навыков как ключевой образовательной компетенции. Интернетжурнал «Эйдос». 2005. 10 сентября. URL: http://www.eidos.ru/journal/2005/0910-09.htm.

[25] Талызина Н. Ф. Формирование познавательной деятельности младших школьников. М., 1988.256 с.

[26] Тлумачний російсько-український словник психологічних термінів (Бродовська В. Й., Грушевський В. О., Патрик І. П.): Словник. К., 2007. 512 с.

[27] Усова А. В. Формирование у учащихся учебных учений. М., 1987. 80 с.

[28] Фридман Л. М. Психолого-педагогические основы обучения математики в школе: Учителю математики о пед. Психологи. М., 1983. 160 c.

[29] Цетлин В. С. Неуспеваемость школьников и ее предупреждение. М., 1977. 120 с.

[30] Шамова Т. И. Активизация учения школьников. М., 1979. 96 с.

[31] Brussels, 17.1.2018 COM(2018) 24 final 2018/0008 (NLE) Proposal for a COUNCIL RECOMMENDATION on Key Competences for Lifelong Learning (Text with EEA relevance) $\{$ SWD(2018) 14 final\}.

\section{REFERENCES (TRANSLATED AND TRANSLITERATED)}

[1] Bantova M. A. Systema formyrovanyia vychyslytelnykh navykov (The System of the Formation of Computing Skills). Nachalnaia shkola. 1993. №11. S. 38 - 43. (in Russian)

[2] Bolshoi psykholohichekyi slovar (Concise Psychological Dictionary). 4-e uzd., rasshyrynoe. Sost. B. H. Meshcheriakov, V. P. Zyncheko. M.: AST Moskva; SPb.: Praim. EVROZNAK, 2009. 811 s. (in Russian)

[3] Vyshnevskyi O. Teoretychni osnovy suchasnoi ukrainskoi pedahohiky (Theoretical Foundations of Modern Ukrainian Pedagogy). Posibnyk dlia studentiv vyshchykh navchalnykh zakladiv. Drohobych, 2006. 326 s. (in Ukrainian)

[4] Vozrastnaia y pedahohycheskaia psykholohyia (Age and Pedagogical Psychology). Ucheb. Posobye dlia studentov ped ynstytutov po spets. 2121 «Pedahohyka y metodyka nach. obuchenyia» / M. V. Matiukhyna, T. S. Mykhalchyk, N. D. Prokyna y dr. Pod red. M. V. Hamezo y dr. M., 1984. 256 s. (in Russian)

[5] Hamezo M. V., Petrova E. A., Orlova L. M. Vozrastnaia y pedahohycheskaia psykholohyia (Age and Pedagogical Psychology): Ucheb. posobye dlia studentov vsekh spetsyalnostei pedahohycheskykh vuzov. M., 2003. 512 s. (in Russian)

[6] Honcharenko S. U. Ukrainskyi pedahohichnyi slovnyk (Ukrainian Pedagogical Dictionary). K., 1997. 375 s. (in Ukrainian)

[7] Ystomyna N. B. Metodyka obuchenyia matematyke v nachalnoi shkole: Razvyvaiushchee obuchenye (Methodology of Teaching Math in Elementary School: Developmental Training). Smolensk, 2005. 272 s. (in Russian)

[8] Koval L. V., Skvortsova S. O. Metodyka navchannia matematyky: teoriia i praktyka (Methodology of Teaching Mathematics: Theory and Practice): Pidruchnyk dlia studentiv za spetsialnistiu 6.010100 «Pochatkove navchannia», osvitno-kvalifikatsiinoho rivnia «bakalavr» [2-he vyd., dopov. i pererobl.]. Kh., 2011. 414 s. (in Ukrainian)

[9] Kostiuk H. S. Navchalno-vykhovnyi protses i psykhichnyi rozvytok osobystosti (Educational Process and Mental Development of Personality). Kyiv, 1989. 608 s. (in Ukrainian)

[10] Lodatko Ye. Matematychna kultura vchytelia pochatkovykh klasiv (Mathematical Culture of Elementary School Teacher). RivneSloviansk, 2011. 324 s. (in Ukrainian)

[11] Lokshyna O. I. Zmist shkilnoi osvity v krainakh Yevropeiskoho Soiuzu: teoriia i praktyka (druha polovyna XX - pochatok XXI st.) (Contents of School Education in the Countries of the European Union: Theory and Practice (Second Half of the XX - Beginning of the XXI Century)). K., 2009. 404 s. (in Ukrainian)

[12] Orlov V. Y. Znanyia, umenyia, navyky y obuchenye (Knowledge, Skills, Habits, and Training). M., 1995. 212 s. (in Russian)

[13] Pavelkiv R. V. Vikova psykholohiia (Age Psychology). K., 2015. 469 s. (in Ukrainian)

[14] Pedahohika (Pedagogy). Za red. A. M. Aleksiuka. K, 1985. 296 s. (in Ukrainian)

[15] Petrovskyi A. V. Obshchaia psykholohyia (General Psychology). M., 1976. 479 s. (in Russian) 
[16] Prykhodko Yu. O., Yurchenko V. I. Psykholohichnyi slovnyk-dovidnyk (Psychological Dictionary-Directory): Navch.posib. 2-he vyd. K., 2014. 314 s. (in Ukrainian)

[17] Proekt Natsionalnoi standartnoi klasyfikatsii osvity (The Draft of National Standard Classification of Education). URL: http:// naps.gov.ua /uploads/ files/sod/NSKO. (in Ukrainian)

[18] Psykholohichnyi tlumachnyi slovnyk suchasnykh terminiv vikovoi ta pedahohichnoi psykholohii (Psychological Thesaurus of Modern Terms of Age and Pedagogical Psychology). URL: http://psichology.com.ua/slovnik-n/; (in Ukrainian)

[19] Rekomendatsiia 2018/0008 (NLE) Yevropeiskoho Parlamentu ta Rady (leS) (Recommendation 2018/0008 (NLE) of the European Parliament and of the Council (EU)). URL: https://ec.europa. eu/education/sites /education/files/ recommendationkey- competences-lifelong-learning.pdf. (in Ukrainian)

[20] Skvortsova S. Vyvchennia pysmovoho dilennia v kursi pochatkovoi matematyky (The Study of Dividing in Writing in the Course of Elementary Mathematics). «Pochatkova osvita». 2002. № 7 (151). S. 4-5. (in Ukrainian)

[21] Skvortsova S. Pryiomy obchyslennia v kursi matematyky pochatkovoi shkoly (Computing Techniques in the Course of Elementary School Mathematics). Materialy mizhnarodnoi naukovo-metodychnoi konferentsii «Problemy matematychnoi osvity» (PMO 2017), m. Cherkasy, 26-28 zhovtnia 2017 r. Cherkasy, 2017. 248 s. (in Ukrainian)

[22] Savchenko O. Ya. Dydaktyka pochatkovoi osvity (Didactics of Elementary Education): pidruchnyk dlia studentiv ped. fakultetiv. K., 2012. 504 s. (in Ukrainian)

[23] Skrypchenko O. V., Dolynska L. V., Ohorodniichuk Z. V., Bulakh I. S., Zelinska T. M. Vikova ta pedahohichna psykholohiia (Age and Pedagogical Psychology): Navch. posibnyk dlia stud. vyshchykh navch. zakl. Vyd. 2-he, dop. K., 2007. 400 s. (in Ukrainian)

[24] Stepashkyna L. Yu. Razvytye obshchykh uchebnykh umenyi y navykov kak kliuchevoi obrazovatelnoi kompetentsyy (Development of General Educational skills and Habits as a Key Educational Competence). Ynternet-zhurnal «Эidos». 2005. 10 sentiabria. URL: http://www.eidos.ru/journal/2005/0910-09.htm. (in Russian)

[25] Talyzyna N. F. Formyrovanye poznavatelnoi deiatelnosty mladshykh shkolnykov (Formation of Cognitive Activity of Younger Schoolchildren). M., 1988. 256 s. (in Russian)

[26] Tlumachnyi rosiisko-ukrainskyi slovnyk psykholohichnykh terminiv (An Interpretative Russian-Ukrainian Dictionary of Psychological Terms) (Brodovska V. Y., Hrushevskyi V. O., Patryk I. P.): Slovnyk. K., 2007. 512 s. (in Ukrainian)

[27] Usova A. V. Formyrovanye u uchashchykhsia uchebnykh umenyi (Formation of Students' Learning Skills). M., 1987. 80 s. (in Russian)

[28] Frydman L. M. Psykholoho-pedahohycheskye osnovy obuchenyia matematyky v shkole (Psychological and Pedagogical Foundations of Teaching Mathematics in School): Uchyteliu matematyky o ped. Psykholohy. M., 1983. 160 s. (in Russian)

[29] Tsetlyn V. S. Neuspevaemost shkolnykov y ee preduprezhdenye (Unsuccessful Learning of Schoolchildren and its Prevention). M., 1977. 120 s. (in Russian)

[30] Shamova T. Y. Aktyvyzatsyia uchenyia shkolnykov (Activization of Schoolchildren's Learning). M., 1979. 96 s. (in Russian)

[31] Brussels, 17.1.2018 COM(2018) 24 final 2018/0008 (NLE) Proposal for a COUNCIL RECOMMENDATION on Key Competences for Lifelong Learning (Text with EEA relevance) $\{\operatorname{SWD}(2018) 14$ final\}. (in English) 